\title{
SPATIAL DESIGN ANALYSIS DALAM PROSES PERENCANAAN DAN PERANCANGAN INTERIOR
}

\author{
Cahyatika Try Widiyanti ${ }^{1}$ dan Rangga Firmansyah ${ }^{2}$, S.Sn., M.Sc \\ Universitas Telkom \\ ${ }^{1}$ cahyatika.widiyanti@gmail.com \\ ${ }^{2}$ ranggafirmansyah@tcis.telkomuniversity.ac.id
}

\begin{abstract}
Abstrak: Perancangan ruang dalam atau yang lebih di kenal dengan sebutan desain interior adalah ilmu yang mempelajari perancangan yang ada di dalam suatu bangunan dan digunakan untuk memecahkan masalah manusia. Salah satu bidang studi keilmuan yang didasarkan pada ilmu desain, bidang keilmuan ini bertujuan untuk dapat menciptakan suatu lingkungan binaan (ruang dalam) beserta elemen-elemen pendukungnya, baik fisik maupun nonfisik. Sehingga kualitas kehidupan manusia yang berada didalamnya menjadi lebih baik.

Proses perancangan interior bertujuan untuk memecahkan masalah yang kompleks berkaitan dengan respon manusia terhadap ruang. Untuk dapat memecahkan masalah secara utuh maka diperlukan sebuah konsep perancangan yang tepat. Keberhasilan konsep perancangan tergantung pada pendekatan yang dilakukan dalam proses penyusunannya.

Konsep spatial interior dapat dibangun dengan cara memahami beberapa hal, meliputi: komponen pemahaman desain, skema perancangan analitis, pemetaan pola pikir desain, metode pendekatan desain, dan diakhiri dengan perumsan konsep desain yang digunakan dalam proses perencanaan \& perancangan interior. Dengan memahami hal-hal tersebut maka sebuah ruang lingkup desain interior dalam memecahkan permasalahan desain diharapkan dapat diselesaikan jelas dan sistematis, sehingga proses penyusunan konsep perencanaan \& perancangan interior yang tepat dapat dilakukan dengan lebih mudah. Konsep yang tepat pada akhirnya akan mampu mengikat hasil perancangan menjadi sebuah desain yang terintegrasi secara utuh.
\end{abstract}

Kata Kunci: Desain Interior, Spatial Desain, Proses Desain

\begin{abstract}
The design of inner space or better known as interior design is the study of design in a building and used to solve human problems. One of scientific studies based on design science, this scientific field aims to be able to create a built environment (inner space) along with its supporting elements, both physical and nonphysical. So that the quality of human life in it becomes better.

The interior design process aims to solve complex problems related to human response to space. To be able to solve the problem in its entirety, it requires an appropriate design concept. The success of the design concept depends on the approach taken in the preparation process.

Interior spatial concepts can be built by understanding several things, including: components of design understanding, analytical design schemes, design mindset mapping, design approach methods, and ending with the design concept used in interior planning \& design processes. By understanding these things, a scope of interior design in solving design problems is expected to be resolved clearly and systematically, so that the process of drafting the proper interior design \& planning concepts can be done more easily. The right concept will eventually be able to tie the design results into a fully integrated design.
\end{abstract}

Keyword: Interior Design, Spatial Design, Design Process

\section{PENDAHULUAN}

Desain merupakan sebuah respon dair perkembangan zaman yang dipengaruhi oleh banyak aspek. Menurut Board of International Research in Design (2008), menjelaskan bahwa desain dapat dipahami sebagai sebuah kegiatan yang kompleks untuk mengoptimalkan aspek psikologi, sosial, kultural, dan ergonomi dari user pada lingkungan terdesain. Desain tidak dapat berdiri sendiri akan tetapi sebuah kolaborasi dari berbagai disiplin ilmu lainnya, seperti ekonomi, lingkungan, wawasan ilmiah dan artistik, ilmu pengetahuan, kebiasaan yang dilaksanakan tiap hari, pengalaman pribadi yang dirasakan pada sebuah artefak tertentu, sistem 
dan proses kehidupan. Simon dalam BIRD (2008) menjelaskan secara sederhananya, sebuah desain itu mengubah kondisi existing sesuai dengan yang diharapkan, tidak jarang kondisi terdesain akan mengubah lingkungan atau berdampak pada lingkungan dan atau sebaliknya. Daur hidup perkembangan sebuah desain itu sebenarnya terus berlangsung.

Dalam proses perancangan dalam desain tidak bisa lagi hanya bertumpu pada akal sehat, pengalaman empirik, dan kotemplasi seseorang saja. Masalah yang dihadapi semakin kompleks, sehingga kualitas desain tidak hanya diukur dari orisinalitas dan daya kreativitas peserta didik dalam menampilkan desain, tapi juga dari penalarannya untuk menguraikan, menjabarkan, menganalisis dan memecahkan masalah yang dihadapi, kemudian mengambil keputusan yang terbaik. Dalam hal ini peserta didik perlu dikondisikan untuk berpandangan secara holistic terhadap berbagai masalah, dan bahkan melampaui lingkup pengaurh langsung untuk mencari kemungkinan-kemungkinan lain. Peserta didik harus mampu mewujudkan kteraturan dari kekacauan (berpikir sistematis) untuk membentuk suatu keteraturan order of importance, menjangkau inti permasalahan, mengabstrasikan-menyuling hingga esensinya atau aspek-aspek informasi utama.

Proses perancangan interior bertujuan untuk memecahkan masalah yang kompleks berkaitan dengan respon manusia terhadap ruang. Untuk dapat memcahkan masalah secara utuh maka diperlukan sebuah konsep perancangan yang tepat. Keberhasilan konsep perancangan tergantung pada pendekatan yang dilakukan dalam proses penyusunannya.

Konsep spatial interior dapat dibangun dengan cara memahami beberapa hal, meliputi: komponen pemahaman desain, skema perancangan analitis, pemetaan pola pikir desain, metode pendekatan desain, dan diakhiri dengan perumusan konsep desain yang digunakan dalam proses perencanaan \& perancangan interior. Dengan memahami hal-hal tersebut maka sebuah ruang lingkup desain interior dalam memecahkan permasalahan desain diharapkan dapat diselesaikan jelas dan sistematis, sehingga proses penyusunan konsep perencanaan \& perancangan interior yang tepat dapat dilakukan dengan lebih mudah. Konsep yang tepat pada akhirnya akan mampu mengikat hasil perancangan menjadi sebuah desain yang terintegrasi secara utuh.

Pada pembahasan diatas dapat ditarik kesimpulan pada permasalahannya adalah bagaimana konsep spatial interior dapat dibangun dengan cara memahami beberapa hal, meliputi: komponen pemahaman desain, skema perancangan analitis, pemetaan pola pikir desain, metode pendekatan desain, dan diakhiri dengan perumusan konsep desain yang digunakan dalam proses perencanaan \& perancangan interior?

Tujuan Penelitian adalah konsep spatial interior dapat dibangun dengan cara memahami beberapa hal, meliputi: komponen pemahaman desain, skema perancangan analitis, pemetaan pola pikir desain, metode pendekatan desain, dan diakhiri dengan perumusan konsep desain yang digunakan dalam proses perencanaan \& perancangan interior.

Menurut Francis D.K. Ching dalam bukunya berjudul Ilustrasi Desain Interior, desain interior adalah merencanakan, menata dan merancang ruang-ruang interior dalam bangunan. Tatanan fisik diatas dapat memenuhi kebutuhan dasar manusia akan sarana untuk bernaung dan berlindung; menentukan langkah sekaligus mengatur bentuk aktivitas manusia; memelihara aspirasi manusia dan mengekspresikan ide-ide yang menyertai segala tindakan manusia; mempengaruhi penampilan, perasaan dan kepribadian manusia. Oleh sebab itu, maksut dan 
tujuan desain interior adalah untuk memperbaiki fungsi, memperkaya nilai estetika dan meningkatkan aspek psikologis dari ruang interior

Setiap desain betujuan menyusun secara teratur bagian demi bagiannya menjadi satu tatanan yang utuh demi maksud-maksud tertentu. Dalam desain interior, elemen-elemen yang dipilih ditata menjadi pola tiga dimensi sesuai dengan garis-garis besar fungsi, estetika dan perilakunya. Hubungan antara elemen-elemen yang terbentuk dari pola-pola ini pada akhirnya menentukan kualitas visual dan kecocokan fungsi suatu ruang interior, dan mempengaruhi bagaimana kita memahami dan menggunakannya.

Menurut Ian Higgins dalam bukunya berjudul Spatial Strategies for Interior Design, desain interior merupakan hal yang berkaitan dengan hubungan manusia dengan ruang bangunan tempat manusia beraktivitas didalamnya. Pada akhirnya, desainer interior harus dapat mempertimbangkan sejumlah masalah hingga yang paling terinci menggunakan strategi desain. Dalam istilah sederhana, hal ini bisa disebut sebagai 'Perencanaan'. Proses perencanaan sendiri dapat dilakukan dengan strategi yang sesuai, mulai dari merencanakan hal yang berbentuk dua dimensi seperti denah hingga dapat diubah menjadi bentuk tiga dimensi yaitu ruang, dengan pertimbangan: volume dan bentuk; proporsi, kedekatan dan hubungan ruang; dan sirkulasi ruang. Semua elemen ini harus dikembangkan dengan mengelola kebutuhan pengguna interior dan menanggapi kendala yang ada mana ruang interior berada. Interior dapat dianggap sebagai penghubung antara bangunan dan penggunanya yang memungkinkannya bekerja untuk tujuan tertentu.

Dalam definisinya, desain interior diartikan sebagai sebuah disiplin ilmu yang mempelajari tentang perencanaan yang terprogram dan perlakuan fisik pada sebuah ruang dalam yang dibatasi oleh tiga elemen, yaitu dinding, lantai dan langit-langit. Pada perkembangannya, pembatasan ini tidak selalu berlaku, bahkan dengan minmal dua elemen pun perancangan sebuah area dapat diaplikasikan. Banyak tempat yang memiliki konsep terbuka, dengan tidak menggunakan elemen dinding ataupun ceiling,perancangan interior alan membantu dalam mencapai konsep tertentu yang dianggap ideal, karena sebuah batas dapat ditandai dengan luas lantai atau langit-langit bahkan dinding. Caan (2011) menjelaskan bahwa dalam sebuah desain interior tidak hanya semata-mata memproses lingkungan fisiknya saja, akan tetapi juga mempertimbangkan dampak atau aspek mental dan psikologisnya, karena ruang atau area tidak hanya digunakan sebagai wadah untuk berkegiatan secara fisik. Sistem tubuh manusia memiliki organ untuk memproses persepsi dan rasa untuk merespon semua hal, tidak luput pada sebuah lingkungan terdesain maupun tidak terdesain. Pada pelaksanaanya, bersinggungan secara langsung, baik sebagai elemen utama ataupun elemen pelengkap bahkan elemen dekorasi atau estetis. Sebagai contohnys: mebel, ragam hias, dan kelengkapan desain lainnya. Dan, akhirnya seorang desainer interior harus dapat mendata segala kebutuhan fisik, psikologis dan mental dari seorang client untuk memperoleh sebuah desain yang optimal.

\section{METODOLOGI PENELITIAN}

Metodologi penelitian yang digunakan yaitu analisis isi (content analysis) dari beberapa buku yaitu Ilustrasi Desain Interior oleh Francis D.K. Ching, Architecture in Use oleh DJM van der Voodrt, How Designer Think \& What Designer Know oleh Brynan Lawson serta Designing Interiors: Second Edition oleh Rosemary Kilmer.

Analisis isi (content analysis) adalah penelitian yang bersifat pembahasan mendalam terhadap isi suatu informasi tertulis atau tercetak dalam media massa. Analisis ini biasanya digunakan 
pada penelitian kualitatif. Pelopor analisis isi adalah Harold D. Lasswell, yang memelopori teknik simbol coding, yaitu mencatat lambang atau pesan secara sistematis, kemudian diberi interpretasi.

Ada beberapa definisi menganai analisis isi. Analisis isi secara umum diartikan sebagai metode yang meliputi semua analisis mengenai isi teks, tetapi di sisi lain analisis isi juga digunakan untuk mendeskripsikan pendekatan analisis yang khusus. Menurut Holsti, metode analisis isi adalah suatu teknik untuk mengambil kesimpulan dengan mengidentifikasi berbagai karakteristik khusus suatu pesan secara objektif, sistematis, dan generalis.

Objektif berarti menurut aturan atau prosedur yang apabila dilaksanakan oleh orang (peneliti) lain dapat menghasilkan kesimpulan yang serupa. Sistematis artinya penetapan isi atau ketegori dilakukan menurut aturan yang diterapkan secara konsisten, meliputi penjaminan sleeksi dan pengkodingan data agar tidak bias. Generalis artinya penemuan harus memiliki referensi teoritis. Inforasi yang didapat dari analisis isi dapat dihubungkan dengan atribut lain dari dokumen dan mempunyai relevansi teoritis tinggi. Definisi lain dari analisis isi yang sering digunakan adalah: research technique for the objective, systematic and quantitative description of the manifest content of communication.

Beberapa pembedaan antara analisis isi dengan metode penelitian yang lain:

1. Analisis isi adalah sebuah metode yang tak mencolok (unobstrusive). Pemanggilan kembali informasi, pembuatan model (modelling), pemanfaatan catatan statistik, dan dalam kadar tertentu, etno-metodologi, punya andil dalam teknik penelitian yang nonreaktif atau tak mencolok ini.

2. Analisis isi menerima bahan yang tidak terstruktur karena lebih leluasa memanfaatkan bahan tersebut dan ada sedikit kebebasan untuk mengolahnya dengan memanggil beberapa informasi.

3. Analisis isi peka konteks sehingga dapat memproses bentuk-bentuk simbolik.

4. Analisis isi dapat menghadapi sejumlah besar data.

Metode content analysis merupakan analisis ilmiah tentang isi pesan suatu komunikasi. Dalam hal ini, content analysis mencakup: klasifikasi tanda-tanda yang dipakai dalam komunikasi, menggunakan kriteria sebagai dasar klasifikasi, dan menggunakan teknik analisis tertentu sebagai pembuat prediksi. Deskripsi yang diberikan para ahli sejak Janis (1949), Barelson (1952), sampai Lindzey dan Aronson (1968) yang dikutip Albert Widjaya dalam desertasinya (1982) tentang content analysis menampilkan tiga syarat, yaitu: objektivitas, dengan menggunakan prosedur serta aturan ilmiah; generalitas, dari setiap penemuan studi mempunyai relevansi teoritis tertentu; dan sistematis, seluruh proses penelitian sistematis dalam kategorisasi data.

\section{HASIL PEMBAHASAN}

Dalam desain interior terdapat suatu proses desain sebagai suatu proses perencanaan dan perancangan desain. Proses desain seringkali disajikan sebagai urut-urutan langkah yang linieir, namun pada kenyataannya proses desain lebih sering berbentuk siklus dimana setiap tahapan merupakan serangkaian analisis, sintesis dan evaluasi yang diteliti mengenai informasi yang tesedia, persepsi, serta kemungkinan solusi yang diulang terus menerus sampai diperoleh perpaduan yang sesuai antara apa yang sudah ada dengan apa yang diinginkan. 


\subsection{Proses Desain Menurut Teori}

Menurut Francis D.K. Ching dalam bukunya berjudul Ilustrasi Desain Interior, proses desain dibagi menjadi tiga tahapan, yaitu:

\section{PROSES DESAIN}

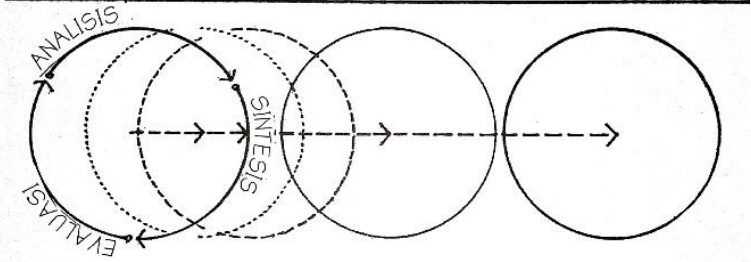

Gambar 1. Diagram Proses Desain Menurut Francis D.K.

\section{A. Analisis}

Kemampuan yang memadai dalam mendefinisikan dan memahami sifat yang terkandung dalam suatu permasalahan desain, merupakan bagian yang penting dari solusinya.

Pada tahapan analisis, desainer harus dapat melakukan penelitian dan analisa yang tepat sehingga dapat menembangkan hipotesis yang dilanjutkan dengan membuat proyeksi-proyeksi desain. Problem desain harus dapat didefinisikan terlebih dahulu. Definisi tersebut harus mencakup spesifikasi mengenai bagaimana melaksanakan solusi desian itu. Tujuan akhir dan tujuan-tujuan lain harus dapat ditetapkan terlebih dahulu.

Analisis suatu permasalahan adalah memecah permasalahan tersebut menjadi beberapa bagian, memperjelas permasalahannya, dan mencoba menerapkan nilai-nilai dari berbagai aspek pada permasalahan itu. Analisis juga melibatkan pengumpulan informasi-informasi yang relevan dan dapat membantu desainer memahami sifat dari permasalahan tersebut dan membangun tahapan yang sesuai. Dari titik tolak ini, perlu diketahui juga batasan apa saja yang akan membantu membentuk solusi desain. Faktor-faktor yang diperoleh apa yang dapat dan tidak dapat diubah, hal ini juga harus dipertimbangkan. Keterbatasan-keterbatasan finansial, hukum atau teknis yang dapat mengganggu solusi desain harus diperhatikan.

Sementara proses desain terus dilakukan, akan semakin tampak pengetian yang lebih jelas tentang permasalahannya. Informasi baru mungkin ditemukan atau dibutuhkan yang mana dapat merubah persepsi desainer terhadap masalah maupun solusinya. Oleh karena itu, analisis terus menerus dilakukan dalam proses desain.

\section{B. Sintesis}

Dari analisis masalah dan bagian-bagian dari masalah tersebut, dapat dimulai membuat formulasi kemungkinan-kemungkinan solusinya. Hal ini memerlukan proses sintesis, yaitu mengggabungkan dan mengintregasikan reaksi-reaksi dari berbagai permasalahan dan aspekaspek masalah tersebut menjadi solusi-solusi yang saling melengkapi.

Desain menuntut pemikiran rasional yang didasarkan atas pengetahuan dan pemahaman yang diperoleh melalui pengalaman dan riset. Intuisi dan imajinasi juga memainkan peranan yang sama pentingnya yaitu menambah dimensi kreativitas dalam proses desain yang rasional. 


\section{Evaluasi}

Desain menuntut tinjauan kritis mengenai alternatif-alternatif dan pembobotan yang hati-hati dari kekuatan dan kelemahan tiap-tiap usulan sampai diperoleh kombinasi terbaik antara masalah dan solusi.

Apabila terdapat beberapa solusi yang memungkinkan, masing-masing dari solusi harus dievaluasi terlebih dahulu sesuai dengan kriteria-kriteria yang telah ditetapkan pada saat mendefinisikan masalah dan kemudian diperjelas kembali pada saat menganalisisnya.

Penyelidikan masalah secara terus-menerus dan peninjauan berbagai alternatif solusinya akan membantu mempersempit ruang lingkup pemilihan untuk pengembangan desain. Sementara tahapan awal proses desain mendorong cara berfikir yang divergen untuk pemahaman masalah, tahap berikutnya justru menuntut pemikiran yang konvergen berfokus pada solusi desain tertentu.

Setelah keputusan akhir diambil, usulan rancangannya mulai dikembangkan, dipersiapkan, kemudian disempurnakan untuk pelaksanaan. Tahap ini meliputi pembuatan gambar-gambar kerja dan spesifikasinya, serta hal-hal lain yang berkaitan dengan pembelian bahan, konstruksi dan supervisinya.

Kesimpulan dari proses desain menurut Francis D.K. Ching dalam bukunya Ilustrasi Desain Interior:

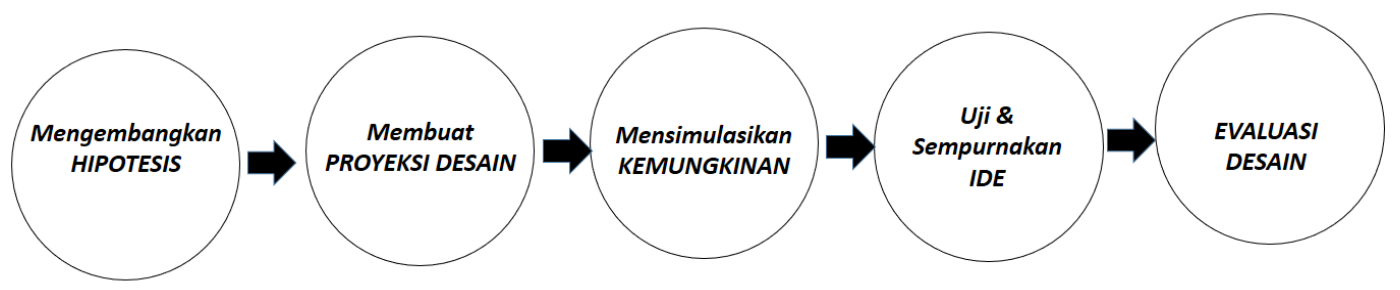

Gambar 2. Diagram Proses Desain Menurut Francis D.K.

Tidak ada proses desain yang lengkap sampai sutau solusi desain yang sudah dilaksanakan dievaluasi efektifitasnya dalam mengatasi suatu masalah. Penilaian ini penting dilakukan pada suatu desain yang telah selesai dibuat karena akan menambah pengetahuan dasar, mempertajam intuisi dan menjadi pelajaran berharga yang mungkin dapat digunakan pada tugas-tugas lain di kemudian hari.

Salah satu keunikan proses desain adalah bahwa proses desain itu tidak selalu menuju hanya ke satu jawaban yang pasti dan benar. Bahkan, sering diperoleh lebih dari satu solusi yang tepat untuk suatu masalah desain. Sebuah desaon dianggap bagus menurut perancangnya, kliennya atau orang lain yang menggunakan desain tersebut, karena salah satu dari beberapa alasan berikut ini:

- Sebuah desain dianggap bagus sebab telah memenuhi fungsinya dengan baik - desain berhasil

- Sebuah desain dianggap bagus sebab biayanya murah - ekonomis, efisien dan tahan lama

- Sebuah desain dianggap bagus sebab tampak indah - secara estetis menyenangkan 
- Sebuah desain dianggap bagus sebab dapat menimbulkan kembali perasaan dan ingatan akan suautu waktu dan tempat - membawa arti

- Sebuah desain mengikuti mode desain yang sedang populer \& menimbulkan impresi pada orang lain - sedang mode dan dapat mengangkat status seseorang

Seperti yang telah diuraikan sebelumnya, ada beberapa macam pesan yang dapat disampaikan oleh suatu desain. Beberapa di antaranya dapat dengan mudah dimengerti dan diterima oleh umum. Sedangkan yang lain baru dapat dihargai oleh sekelompok orang tertentu saja. Desain yang sukses biasanya dapat menyampaikan lebih dari satu pesan sehingga dapat menarik perhatian banyak orang.

Oleh karena itu, sebuah desain yang baik harus dapat dimengerti. Mengetahui mengapa sesuatu telah dilakukan membuat desain menjadi komprehensif. Jika suatu desain tidak mengeskpresikan suatu ide, menyampaikan suatu pesan, atau mengundang tanggapan, maka desain tersebut tidak akan diperhatikan atau menjadi desain yang buruk.

Selain teori proses desain menurut Francis D.K. Ching, terdapat teori proses desain menurut DJM van der Voordt dan HBR van Wegen dalam bukunya yang berjudul "Architecture In Use", yang menyebutkan salah satu metodologi desain paling terkenal dari periode awal adalah dari J.C. Jones. Pada 1963 ia menerbitkan artikel “A Method of Systematic Design”. Menurut Jones, proses desain dimulai dengan yang tahap pertama yaitu programming. Pemrograman umumnya dipandang sebagai sistem pemrosesan informasi menetapkan arah desain yang akan mengakomodasi kebutuhan pengguna, klien, perancang, atau pengembang (Sanoff, 1992). Selain itu pengertian lain dari progamming adalah dokumen yang berfungsi untuk menggabungkan ke dalam proses desain komunikasi antara klien dan pengguna di masa mendatang bangunan di satu sisi dan arsitek dan konsultan di sisi lain, sejalan dengan asumsi dasar dan memperhatikan kondisi yang akan terjadi, kebutuhan, persyaratan, harapan dan harapan klien dan pengguna di masa mendatang, melalui serangkaian kegiatan yang koheren, dirancang untuk mencapai koleksi, pemrosesan, evaluasi yang lengkap dan tidak ambigu dan transmisi informasi, secara bertahap dari global ke detail. Bagan berikut menunjukkan proses dari sebuah programming:

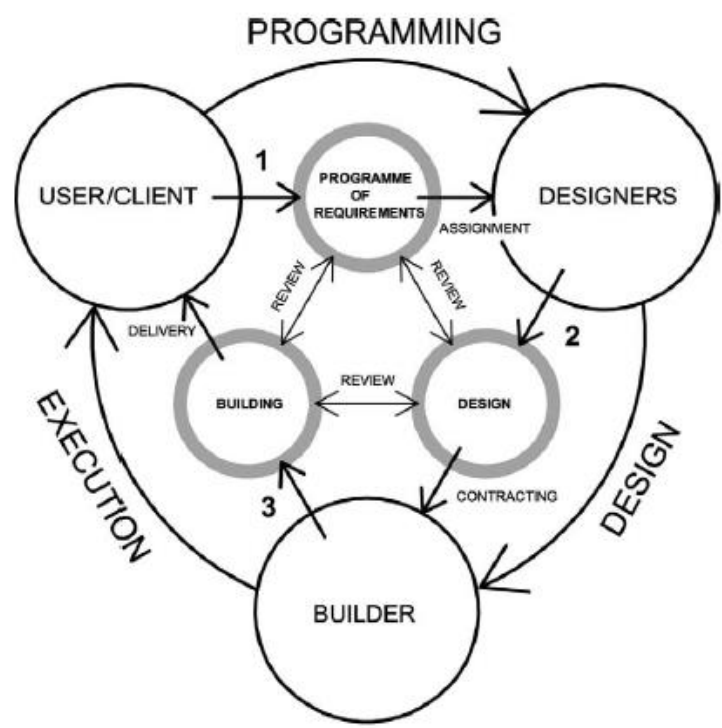

Gambar 3. Diagram Programming. Source: Vrielink (1991) 
Kemudian tahap yang kedua yaitu transformation (menyusun masalah \& memikirkan solusi desain) dan yang terakhir yaitu convergence (menyusun solusi-solusi dan evaluasi desain). Jones menyatakan tiga fase utama dalam proses ini, yaitu:

1. Analisis: menggambarkan masalah secara keseluruhan dan memecahnya menjadi komponen individu, mengidentifikasi setiap persyaratan desain dan mengatur hasil untuk membentuk satu set persyaratan kinerja yang konsisten.

2. Sintesis: mengembangkan solusi untuk bagian-bagian masalah dan persyaratan kinerja khusus dan mencapai integrasi terbaik solusi parsial menjadi desain yang lengkap.

3. Evaluasi: menentukan sejauh mana solusi akhir dan persyaratan yang ditetapkan sebelumnya.

\subsection{Bagian-Bagian dalam Proses Desain}

\section{A. Manusia \& Penataan Ruang}

\section{1) Profil Pengguna}

Menurut Francis D.K. Ching dalam bukunya "Ilustrasi

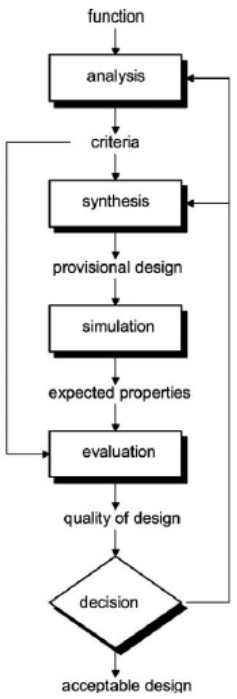

Desain Interior", kriteria utama untuk menilai

keberhasilan interior desain apakah berfungsi atau tidak adalah tingkat desain yang paling mendasar sudah sesuai fungsi atau tidak. Desainer merancang untuk meningkatkan fungsi ruang interior dan membuat kegiatan yang dilakukan di dalamnya lebih nyaman dan menyenangkan. Pemfungsian desain yang tepat, tentu saja, terkait langsung dengan tujuan mereka yang mendiami dan menggunakannya, serta fisik, dimensi dan kemampuan. Untuk memahami dan memenuhi fungsi dan tujuan ruang interior, diperlukan perancang untuk menganalisis dengan seksama pengguna dan aktivitas persyaratan untuk ruang itu. Garis besar berikut bisa membantu program perancang persyaratan ini, terjemahkan kebutuhan ini ke dalam bentuk dan pola, dan mengintegrasikannya ke dalam konteks spasial.

Cara untuk mendapatkan data dari profil pengguna yaitu melakukan wawancara dengan user. Hal-hal yang harus dianalisis dari user yaitu identifikasi pengguna, identifikasi kebutuhan, menetapkan persyaratan teritorial, menentukan preferensi dan penelitian masalah lingkungan.

\section{2) Aktivitas}

Menurut Francis D.K. Ching dalam bukunya "Ilustrasi Desain Interior”, selain desainer harus menganalisa profil dari user, desainer juga harus dapat menganalisa akitivitasnya. Aktivitasnya dibedakan menjadi aktivitas utama, aktivitas pendukung, dan aktivitas servis.

Selain menentukan prioritas dari aktivitas, juga dapat menganalisa persyaratan dari beberapa hal seperti identifikasi aktivitas primer, sekunder; menganalisis sifat dari kegiatan dan menentukan persyaratan lain seperti privasu, aksesibilitas, fleksibilitas, cahaya, kemanan, dll.

\section{3) Sirkulasi}

Menurut Ian Higgins dalam bukunya yang berjudul "Spatial Strategies for Interior Design" menyebutkan bahwa dalam hal desain interior, sirkulasi melibatkan cara-cara di mana pengguna menavigasi ruang di dalam gedung. Karena kebanyakan bangunan terdiri dari lebih dari satu ruang tunggal, strategi sirkulasi berkaitan dengan akses antar ruang oleh pengguna. 
Di sebagian besar bangunan, pengguna mengambil rute mereka sendiri melalui ruang yang disediakan sebagai tanggapan terhadap pembatasan yang ditempatkan pada mereka, yang memungkinkan setiap pengunjung untuk berkeliling bangunan dengan cara yang berbeda. Betapapun rumitnya strategi sirkulasi bangunan bisa menjadi, satu hal tetap sederhana: ketika orang-orang bersirkulasi melalui bangunan mereka mengambil jalan dan menurut sifatnya linier adalah rute yang membawa pengguna pada suatu perjalanan melalui waktu dan ruang. Menurut Ian, semua jenis sirkulasi merupakan aktivitas yang linier. Prinsip inilah yang menopang formasi strategi sirkulasi yang memungkinkan orang untuk bernavigasi bangunan sesuai kebutuhan. Rute srikulasi linier dapat diatur kedalam sirkulasi radial, sirkulasi spiral, sirkulasi grid dan sirkulasi network.

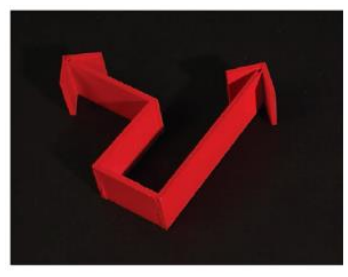

\section{4) Organisasi Ruang}

Ian Higgins menyebutkan dalam bukunya yang berjudul "Spatial

Gambar 5.Sirkulasi Linier

Strategies for Interior Design”, organisasi ruang dalam interior adalah pembagian tata ruang pada bentukan ruang yang sudah ada. Organisasi ruang dibagi menjadi lima, yaitu organisasi ruang linier, organisasi ruang radial, organisasi ruang grid, organisasi ruang central, organisasi ruang cluster serta organisasi ruang gabungan.

\section{5) Zoning}

Menurut Francis D.K.Ching dalam bukunya "Ilustrasi Desain Interior", menyatakan bahwa untuk menentukan zoning ruangan maka sebelumnya harus dilakukan analisa kebutuhan ruang dari aktivitas yang telah dianalisa yang disebut tabel kebutuhan ruang. Dari tabel tersebut dapat diketahui dimensi kebutuhan luas dari suatu aktivitas.

Analysis of User Requirements + Existing or Proposed Spaces... Integration
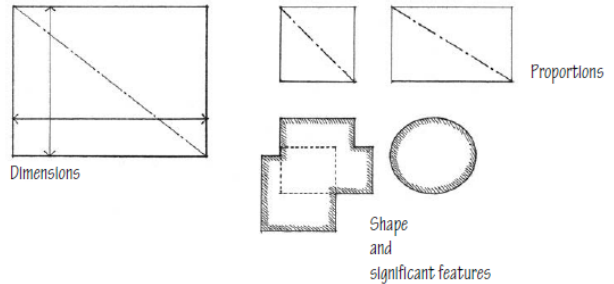

Gambar 6. Diagram penentuan kebutuhan

Setelah itu, perlu dilakukan pula sanalisa keterkaitan \& kedekatan dari aktivitas yang digambar dalam buble diagram. Desainer interior berusaha untuk kesesuaian yang tepat antara tuntutan kegiatan dan sifat arsitektural dari ruang yang menampung mereka. Aktivitas tertentu mungkin perlu terkait erat atau berdekatan satu sama lain, sementara yang lain mungkin lebih jauh atau terisolasi untuk privasi. Beberapa kegiatan mungkin membutuhkan akses mudah, sementara yang lain mungkin membutuhkan entri terkontrol dan keluar. Pencahayaan alami dan ventilasi alami mungkin prioritas untuk beberapa area, sementara yang lain mungkin tidak perlu terletak di dekat jendela eksterior. Beberapa kegiatan mungkin ada persyaratan spasial spesifik, sementara yang lain mungkin lebih fleksibel atau dapat berbagi ruang bersama. 

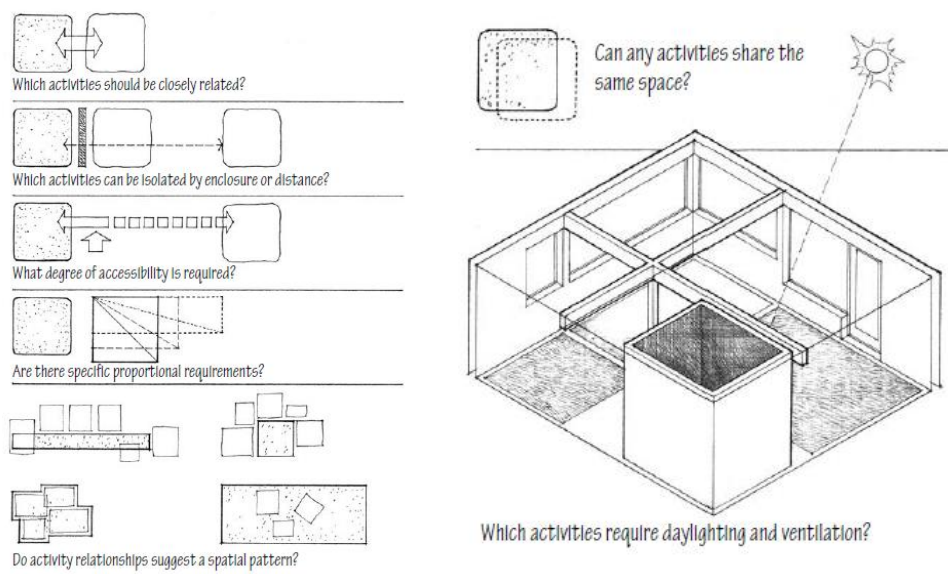

Gambar 7. Diagram analisa kedekatan dan keterkaitan aktivitas

\section{6) Layout}

Layout adalah rencana adalah proyeksi ortografi dari suatu objek, struktur, atau komposisi pada bidang horizontal. Denah lantai merepresentasikan suatu bagian melalui sebuah bangunan atau bagian gedung setelah potongan horizontal dibuat, biasanya sekitar empat kaki (sekitar 1,2 m) di atas lantai, dan bagian atas dihilangkan.

Menurut Francis D.K.Ching dalam bukunya "Ilustrasi Desain Interior", menyatakan bahwa tata ruang dan perencanaan ruang merupakan bagian integral dari desain interior. Tujuan desainer yaitu menggunakan ruang secara efisien, memiliki aliran yang berkelanjutan dan baik dalam ruang dan untuk menciptakan suasana yang indah dan diinginkan. Desainer merancang penempatan furnitur dan elemen arsitektur adalah dasar untuk hasil desain yang hebat. Pentingnya skala dan ukuran dalam rencana desain serta penggunaan area yang paling efisien dapat menentukan tercapainya suatu desain layout yang baik.

\section{B. Karakter Ruang}

\section{1) Tema}

Tema suatu pola utama atau ide dasar yang dijadikan acuan utama dalam merancang desain proyek, contoh tema kemaritiman, go green, bhineka nusantara, dan lain-lain.

\section{2) Gaya}

Gaya desain interior adalah ragam atau corak yang digunakan sebagai ekspresi kepribadian untuk memecahkan permasalahan desain interior, mencakup unsur-unsur bentuk, konstruksi, bahan, warna dan karakter daerah. Gaya dapat berubah sesuai perkembangan jaman seperti mode.

\section{3) Warna}

Warna merupakan sifat dasar visual yang dimiliki oleh semua bentuk. Warna yang tampak pada benda bersumber pada cahaya yang menyinarinya sehingga memperlihatkan adanya bentuk dan ruang. Tanpa cahaya, warna tidak akan ada. Warna adalah salah satu elemen penting dalam sebuah interior. Penentuan warna yang pas sangat penting untuk membangun suasana yang ingin diciptakan dalam ruangan tersebut.

Menurut Rosemary Kilmer dalam bukunya berjudul "Designing Interiors" menyatakan bahwa untuk memahami efek, hubungan, dan aplikasi warna, akan sangat membantu untuk mengatur warna menjadi sistematis klasifikasi atau teori. Sebelum salah satu sistem warna dapat dijelaskan, bagaimanapun, adalah penting untuk memahami hubungan antara warna-warna 
utama cahaya dan warna-warna primer pigmen, dan bagaimana hal ini bercampur menghasilkan warna lain.

\section{4) Tekstur}

Menurut Francis D.K. Ching dalam bukunya "Ilustrasi Desain Interior", tekstur adalah kualitas tertentu suatu permukaan yang timbul sebagai akibat dari struktur 3 dimensi. Tekstur paling sering digunakan untuk menjelaskan tingkat kehalusan atau kekerasan relatif suatu permukaan. Tekstur juga dapat digunakan untuk menjelaskan karakteristik kualitas permukaan pada material-material yang mirip satu sama lain, seperti kekasaran batu, garis-garis urat kayu dan tenunan kain.

\section{5) Suasana}

Suasana merupakan athmosphere yang ingin ditampilkan dalam suatu ruang. Hubungan yang sifatnya timbal balik antara suasana ruang (atmosphere) dengan kegiatan manusia sangat dipengaruhi oleh faktor desain dan karakteristik dominan manusia yang berinteraksi di dalamnya. Sebagai kualitas lingkungan, suasana ruang merupakan masukan pada manusia yang kemudian dikonversikan oleh manusia menjadi persepsi dan pada tingkah laku (kegiatan). Sebaliknya, kegiatan manusia itu sendiri dapat mempengaruhi suasana ruang, sehingga karakteristik yang dominan sebagai latarbelakang dari sifat dan jenis kegiatan manusia tersebut secara umum turut berpengaruh pula pada suasana ruang yang melingkupinya.

\section{6) Elemen Estetis}

Elemen estetis merupakan elemen pendukung atau dekorasi dalam interior. Elemen estetis erat hubungannya dengan pensuasanaan ruang. Elemen estetis biasanya digunakan guna untuk mendukung dan mempertegas suasana ruang yang akan ditampilkan pada ruang. Elemen estetis dan aksesori pada ruangan seperti hiasan meja, dinding, dan sebagainya juga turut menentukan. Aksesori sangat dekat dengan ketiga prinsip desain yaitu dekat dengan fungsi ruang, suasana ruang yang ingin diciptakan, dan harmoni yang terangkat dalam ruang.

\section{Pengisi Ruang}

\section{1) Furniture}

Menurut Rosemary Kilmer dalam bukunya berjudul "Designing Interiors" menyatakan bahwa furniture adalah elemen integral dalam desain ruang interior karena mempengaruhi fungsi dan keinginan manusia, seperti duduk, bekerja, tidur, dan santai. Furnitur juga menyediakan personalisasi ruang yang direfleksikan preferensi, kegiatan, dan kebutuhan individu. Sebagian besar ruang interior membutuhkan furnitur, yang dapat mendukung kegiatan penggunanya.

\section{2) Peralatan}

Menurut Rosemary Kilmer dalam bukunya berjudul "Designing Interiors" menyatakan bahwa memilih peralatan untuk proyek desain interior melibatkan barang-barang baik yang secara fisik melekat pada bangunan atau berdiri bebas, termasuk peralatan untuk toilet, dapur, perpustakaan, dan ruang laboratorium. Desainer interior bekerja dengan pengguna, pemasang, dealer, dan pabrikan untuk mendapatkan informasi dan panduan spesifik untuk digunakan saat memilih peralatan ini. Konsultan, seperti spesialis dapur komersial, dapat dipanggil untuk membuat presentasi tentang peralatan atau memberikan rekomendasi tentang anggaran dan peralatan khusus. 


\section{Elemen Pembentuk Ruang}

Berdasarkan Buku Ilustrasi Desain Interior oleh Francis D.K. Ching, ruang-ruang itnerior dalam bangunan dibentuk oleh elemen-elemen yang bersifat arsitektur dari struktur dan pembentuk ruangnya, seperti kolom, dinding, lantai dan atap. Elemen-elemen tersebut memberi bentuk pada bangunan, memisahkan dari ruang luar, dan membentuk pola tatanan ruang interior. Dengan elemen-elemen pembentuk ruang ini digunakan untuk mengembangkan, memodifikasi dan memperindah ruang-ruang yang membuatnya dapat dihuni dan cocok dari segi fungsi, estetika dan psikologis.

\section{1) Lantai}

Lantai merupakan bidang ruang interior yang datar dan mempunyai dasar yang rata. Sebagai bidang dasar yang menyangga aktivitas interior dan perabot kita. Lantai harus terstruktur sehingga mampu memikul beban tersebut dengan aman, dan permukannya harus cukup kuat untuk menahan penggunaan. Lantai harus memenuhi dua kriteria, yaitu kriteria fungsional dan juga kriteria estetis. Sebagai kriteria fungsional, lantai harus dapat mendukung kegiatan pengguna diatasnya. Sebagai kriteria estetis, lantai dapat didesain netral atau bermotif. Lantai netral dan tidak bermotif dapat berfungsi sebagai latar belakang yang sederhana untuk penghuni dan perabotannya. Sedangkan lantai bermotif/pola dapat menjadi elemen yang dominan dalam ruang interior. Pola tersebut dapat digunaka untuk menentukan bagian ruang yang menunjukkan sirkulasi atau sekedar sebagai daya tarik tekstur.

\section{2) Dinding}

Dinding adalah elemen arsitektur yang penting untuk setiap bangunan. Dinding berfungsi sebagai struktur pemikul lantai diatas permukaan tanah, langit-langit dan atap. Menjadi muka bangunan dan memberi proteksi dan privasi pada ruang interior yang dibentuknya. Dinding sebagai elemen utama yang dengannya kita dapat membentuk ruang interior. Dinding dapat mengendalikan ukuran dan bentuk ruang.

Dinding yang stabil, akurat dan simetris akan memberikan kesan formal, yang dapat didesain dengan menggunakan tekstur yang halus. Dinding yang tidak teratur terlihat lebih dinamis. Apabila dikombinasi dengan tekstur kaksar, dinding akan memberi kesan internal tehadap suatu ruang.

\section{3) Plafon}

Plafon atau langit-langit adalah elemen yang menjadi naungan dalam desain interior, dan menyediakan perlindungan fisik maupun psikologis untuk semua yang ada dibawahnya. Mesikpun berada diluar batas jangkauan tangan kita dan tidak digunakan seperti halnya lantai dan dinding, langit-langit memainkan peran visual penting dalam pembentukan ruang interior dan dimensi vertikalnya.

Ketinggian langit-langit mempunyai pengaruh besar terhadap skala ruang. Sementara ketinggian langit-langit harus dipertimbangkan relatif terhadap dimensi-dimensi ruang yang lain dan pemakaian dan penggunaanya, beberapa kriteria umum masih dpat dibaut untuk dimensi vertikal ruang. Langit-langit yang tinggi cenderung menjadikan ruang teraa terbuka, segar dan luas. Dapat juga memberi suasana agung atau resmi, khususnya jika rupa dan bentuknya beraturan. Tidak sekedar menutup ruang tetapi menjulang keatas. Sedangkan langitlangit rendah, sebaliknya, mempertegas kualitas naungannya dan cenderung menciptakan suasana intim dan ramah. 


\section{E. Tata Kondisi Ruang}

\section{1) Pencahayaan}

Cahaya mempengaruhi penataan interior dalam hal :

- Menentukan atmosfer ruang

- Mempengaruhi mood pengguna

- Mendukung fungsi ruang

Pada perancangan interior, jenis tata cahaya dapat dibagi menjadi pencahayaan alami dan pencahayaan buatan.

a. Pencahayaan alami

Pencahayaan alami adalah proses menempatkan jendela, bukaan, dan permukaan reflektif lainnya sehingga pada siang hari ruangan tersebut dapat menyediakan cahaya alami yang efektif ke dalam ruangan.

b. Pencahayaan buatan

Pencahayaan buatan terkait dengan penemuan ornamen sumber cahaya itu sendiri.

\section{2) Penghawaan}

Berdasarkan Buku Ilustrasi Desain Interior oleh Francis D.K. Ching, penghawaan dalam interior erat kaitannya dengan kenyamanan termal yang dirasakan oleh pengguna ruang didalamnya. Kenyamanan termal dicapai ketika tubuh manusia mampu mengusir panas dan kelembaban yang dihasilkannya oleh tindakan metabolisme, untuk menjaga tubuh yang stabil dan normal suhu.

\section{3) Akustik}

Berdasarkan Buku Ilustrasi Desain Interior oleh Francis D.K. Ching, akustik berurusan dengan produksi, kontrol, transmisi, penerimaan, dan efek suara. Suara terjadi ketika energi ditransmisikan sebagai tekanan gelombang melalui udara atau medium lain. Sebuah suara gelombang bergerak ke luar secara spheris dari sumbernya sampai itu menemui rintangan di jalannya. Saat gelombang suara pemogokan objek, itu diserap atau dipantulkan, atau kombinasi keduanya.

\section{F. Mechanical \& Electrical, Sign System}

Mekanikal dan Elektrikal dalam bangunan adalah sistem-sistem pendukung bangunan yang memerlukan sebuah sistem mekanis dan sistem yang memerlukan tenaga listrik. Sistem sistem pendukung tersebut diaplikasikan dalam bangunan untuk tujuan menunjang kegiatan yang dilakukan dalam bangunan, termasuk dalam hal kenyamanan dan keamanan bagi setiap aktivitas dan pelakunya di dalam bangunan tersebut. Untuk membuat ruangan tersebut aman dan nyaman, diperlukan penerapan ilmu mekanikal eletrikal yaitu sistem pengkondisian tata udara, pergantian udara, sistem tata cahaya dan juga sistem keamanan seperti fire fighting \& dan alarm. 


\section{DISKUSI/PEMBAHASAN}

Desain interior memiliki suatu proses desain yang pasti. Proses desain dalam perencanaan dan perancangan interior merupakan proses yang skematik dan teratur. Proses desain perencanaan dan perancangan interior dapat disimpulkan dalam diagram pola desain perencanaan dan perancangan interior sebagai berikut:

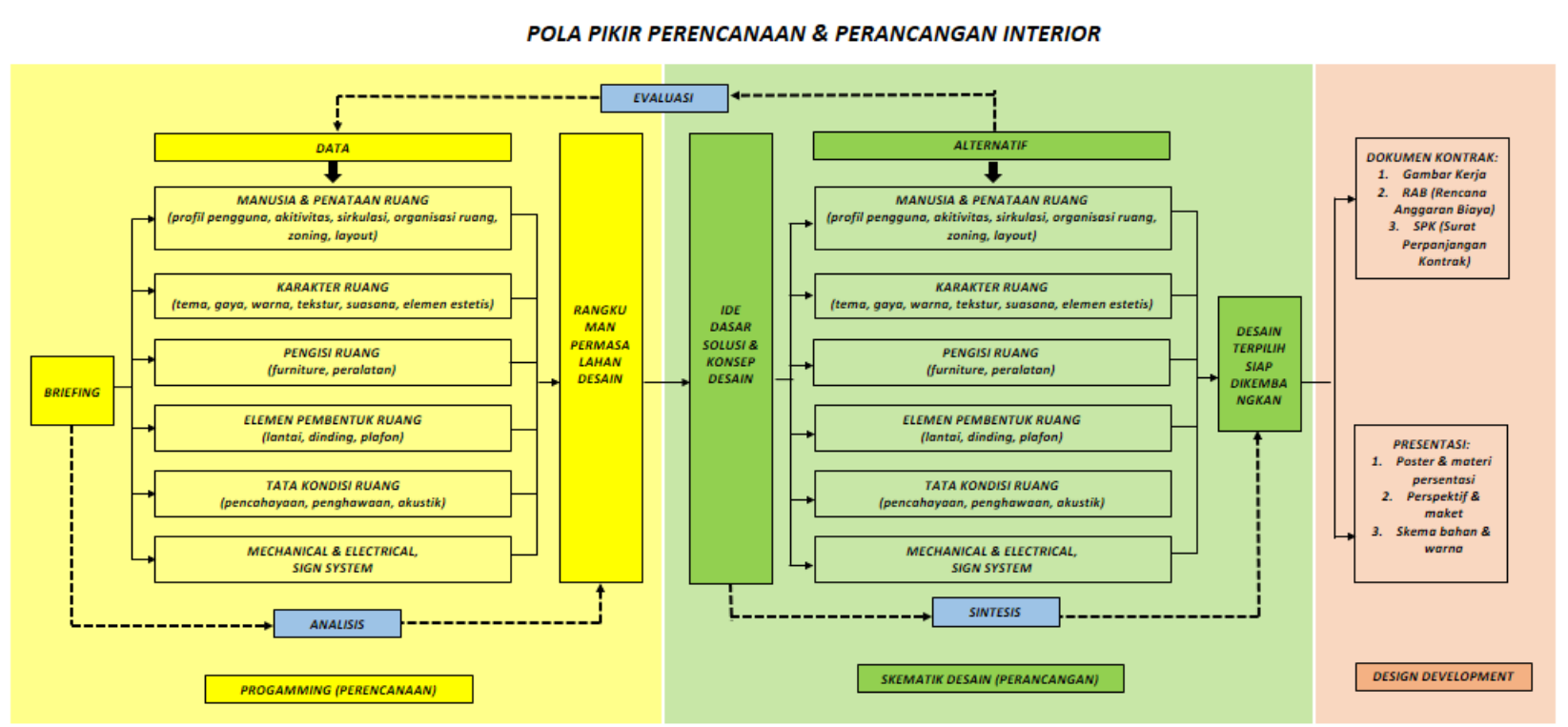

Gambar 8. Diagram Pola Perencanaan \& Perancangan Interior

\section{KESIMPULAN}

Proses perancangan interior bertujuan untuk memecahkan masalah yang kompleks berkaitan dengan respon manusia terhadap ruang. Untuk dapat memecahkan masalah secara utuh maka diperlukan sebuah konsep perancangan yang tepat. Keberhasilan konsep perancangan tergantung pada pendekatan yang dilakukan dalam proses penyusunannya. Konsep spatial interior dapat dibangun dengan cara memahami beberapa hal, meliputi: komponen pemahaman desain, skema perancangan analitis, pemetaan pola pikir desain, metode pendekatan desain, dan diakhiri dengan perumsan konsep desain yang digunakan dalam proses perencanaan \& perancangan interior. Dengan memahami hal-hal tersebut maka sebuah ruang lingkup desain interior dalam memecahkan permasalahan desain diharapkan dapat diselesaikan jelas dan sistematis, sehingga proses penyusunan konsep perencanaan \& perancangan interior yang tepat dapat dilakukan dengan lebih mudah. Konsep yang tepat pada akhirnya akan mampu mengikat hasil perancangan menjadi sebuah desain yang terintegrasi secara utuh.

\section{DAFTAR PUSTAKA}

Laksmi Kusuma Wardani, BERFIKIR KRITIS KREATIF, Sebuah Model Pendidikan di Bidang Desain Interior, http://puslit.petra.ac.id/journals/interior/, (diunduh 2 April 2016) 
Yusita Kusumarini, 2005, Unsur Desain (Spesifik) Dalam Pembelajaran Dasar Desain Interior, Jurnal Dimensi Interior, PETRA Surabaya, Vol. 3, No. 1 Juni 2005: 31-43

Rahmawan D. Prasetya, 2013, Peran Aktif Desainer Interior Dalam Pengembangan Industri Kreatif, Jurnal Lintas Ruang Vol. 3, (diunduh 2 April 2016)

Adi Santosa, 2006, Pendekatan Konseptual Dalam Proses Perancangan Interior, http://puslit.petra.ac.id/journals/interior/, (diunduh 2 April 2016)

Michael Erlhoff \& Tim Marshall, 2008, Design Dictionary, Perspectives on Design Terminology, Birkhauser Verlag AG, Berlin

Tim Kurikulum \& Pembelajaran, Direktorat Pembelajaran \& Kemahasiswaan, Direktorat Jenderal Pendidikan Tinggi Kementrian Pendidikan \& Kebudayaan, 2014, Buku Kurikulum Pendidikan Tinggi, Jakarta

Francis D.K. Ching, 2000, Ilustrasi Desain Interior, Erlangga Jakarta

DJM van der Voordt \& HBR van Wegen, 2005, Architecture In Use, Elsevier London

Brynan Lawson, 2005, How Designer Think, Elsevier London

Brynan Lawson, 2005, What Designer Know, Elsevier London

Rosemary Kilmer \& W. Otie Kilmer, 2014, Designing Interiors: Second Edition, Wiley United States of America 